Article

\title{
Presence of New Forms of Intercultural Communication in Higher Education: Emojis and Social Interactions through WhatsApp among Graduate Students
}

\author{
María Guadalupe Veytia-Bucheli ${ }^{1}$ (D) José Gómez-Galán ${ }^{2,3, *(D)}$ and Diego Vergara ${ }^{4}$ (D) \\ 1 Institute of Social Sciences and Humanities, Autonomous University of Hidalgo State, Actopan 42039, \\ Mexico; mgpeveytia@hotmail.com \\ 2 Department of Education, University of Extremadura, Avda. de Elvas, s/n 06006 Badajoz, Spain \\ 3 College of Education, Ana G. Méndez University, Cupey Campus, San Juan, PR 00926, USA \\ 4 Technological Department, Catholic University 'Santa Teresa de Jesús' of Ávila, C/Canteros, \\ s/n 05005 Ávila, Spain; diego.vergara@ucavila.es \\ * Correspondence: jogomez@uagm.edu
}

Received: 2 September 2020; Accepted: 13 October 2020; Published: 22 October 2020

\begin{abstract}
Communication processes are part of human life. Information and communication technologies (ICTs) and, especially, the use of smartphones have generated new forms of interaction and communication, both synchronous and asynchronous, in formal and informal spaces. One of the most used applications is WhatsApp, which allows the sending of text, documents, images, and emojis. It is important to study these new forms and languages of communication in higher education because any educational or training process is essentially communicative. This research was carried out using a mixed approach, with a nonexperimental, descriptive, and transversal design, using a technique of a survey made up of 30 items. It was applied to postgraduate university students to determine their use and value among people with a consolidated university academic career, which would allow us to determine the presence of these new languages in this context. The basic objectives were to identify the frequency of use of emojis through WhatsApp amongst Mexican graduate students and to analyze the advantages and disadvantages of their use. The results confirmed the increase of emojis in conversations conducted by WhatsApp among fellow students. As positive elements, it was determined that they favor the development of a pleasant environment, confidence, and empathy, in addition to expressing emotions, feelings, and reactions. However, emojis also have drawbacks and disadvantages. Among them is the risk that they are misunderstood since their meaning is not shared, that they divert attention from a central idea, and, in general, that they sometimes have an addictive character that implies a waste of time in a study context, such as at the university. In conclusion, it can be argued that ICTs are profoundly transforming the processes of written communication in today's society, including the university world. New languages that present intercultural, dynamic, dialectic, and ecosystemic alternatives to speech or writing have appeared. Emojis, in the context of higher education, would be an example of this trend.
\end{abstract}

Keywords: emojis; interactions; WhatsApp; communication; higher education; students; graduate

\section{Introduction}

Communication is one of the indispensable activities for human beings to live together in society and generate knowledge [1,2]. It allows them to expose ideas, points of view, opinions, comments, feelings, emotions, and moods about a certain concept, fact, or situation. In a written way, it is formed 
by a series of symbols, and, if the oral form is used, the corporal language is also printed, as well as the tone of voice, which allows the confirmation of what is expressed when attributing a greater sense and meaning [3]. In this way, the use of emotions in faces is a fundamental aspect of nonverbal communication in the daily life of human beings [4].

Currently, in the context of Web 2.0, multiple technological applications are used to for daily activities of various kinds, such as making payments, shopping, searching for information, listening to music, workout routines, and publishing photographs [5], creating new ways of communicating and relating, individually or in groups [6,7], both synchronously-e.g., through videoconferences—and asynchronously—for example, with the use of chat applications. For this purpose, different formats are used, such as text, images, audio, and video, particularly through the use of the mobile or cell phone [8]; in this way, the barriers of time and distance are overcome [9].

Other authors [10] state that with the expansion of digital media, the processes of speaking and writing can be defined as mixed; this combination is mainly established using technological applications on different mobile devices, in which the same linguistic code is handled for both the sender and the receiver. Young people are the largest age group taking part in these conversations, although little by little, people of different ages have joined in, which has changed the way of communicating and writing through the use of various signs, symbols, and emojis [11].

Technology-mediated communication (TMC), which is defined as the process that is generated between communication and technological tools, is increasingly used every year $[12,13]$. TMC has evolved through different times $[1,14]$, thereby allowing the storage, transmission, and/or processing of the information in different ways. In particular, at present, the development that has taken place in terms of technological advances and applications has been significant $[3,15]$.

The language used through information and communication technologies (ICTs) includes not only written text but also audio and images, which are notorious in conversations that take place through different applications, one of the most used of which is WhatsApp. These are characterized by their generally short length [16], in the space of which the use of emojis is incorporated [15]. Emojis are images that allow the representation of gestures, emotions, and feelings. Additionally, the vertical and unidirectional communication model has moved toward a horizontal and multidirectional one, where the subjects become both consumers and producers of information [17], playing an active role in participation in forums, blogs, and wikis, which favor collaborative work $[18,19]$.

Particularly when talking about chats, previous research works [20] argue that they are a space conducive to working with ultra-fast responses, where communication with a group of people and communication with several groups of people simultaneously are also possible, so that the speed of reading has increased in proportion to the speed of response through the use of signs, symbols, and abbreviations, which allow time efficiency. The use of online messages has presented the development of new communicative behaviors of users; it is stated that communication is carried out more with characters than with people [5].

As they are widely spread in the social field, all these innovative forms of communication have their presence in the educational world and, specifically, in higher education. Of course, these are not formal learning processes in the usual sense of this concept [21-24] since the new communicative languages do not form part of the regulated university programs. In the development of these forms of expression in the university context, the acquisition of these communicative skills comes from the field of informal learning [25-28]. They would form part of the very diverse processes of the impact that today's digital technologies and social media also have on higher educational levels [29-35] - a presence that is even blurring the boundaries between formal and informal learning [36] and exercising its influence in multiple areas that are currently being transformed [37-40].

Although the university institutions are not very permeable to change and present deep-rooted immobilized forces, they cannot remain unaware of the social revolution that the digital paradigm is bringing about. With a greater or lesser presence in educational policies, the integration of ICTs in university contexts is unstoppable, and all the new intercultural communication forms of the 
globalization that the technological revolution is promoting are present in it. This is even more so if we take into account, as is clear, that every educational or training process is, above all, a communicative process $[41,42]$ in which writing and knowing the influence that the digital revolution has on it is fundamental.

\section{Background}

\subsection{Presence of New Forms of Communication in Higher Education}

It is in this sense that the interest in investigating the new writing languages has recently increased significantly from different disciplines such as psychology, medicine, communication, law, and education [43]; added to this is the protagonist that emojis gain in the conversations employing different applications such as Facebook, Twitter, and WhatsApp, both person to person and in groups, which reduces the response time but, at the same time, displaces conventional practices [44-46].

Some research that revolves around this object of study has questioned how communicative processes are carried out and the changes generated through writing, which has increased the speed of response and sometimes neglects questions related to grammar and spelling [20,47,48].

Particularly with the use of emojis, one finds studies related mostly to the practices of young university students and, particularly, to the processes of writing, grammar, and spelling. Focusing on the Spanish-speaking context, for example, contributions in this sense and with diverse research approaches are increasingly frequent: Prieto-Terrones and Sanz-Martin [49] analyze the acceptance of writing in virtuality, mainly through WhatsApp, where it is recognized and accepted by users, highlighting the ease it has for quick communication; Cantamutto and Vela [50] conducted a comparative study where they analyze the interactions of WhatsApp and incorporating emojis amongst students from Argentina and Spain; Giraldo et al. [20] analyzed grammar and writing with the use of technological tools; Giraldo [51] reflected on the traditional way of writing and the writing carried out by WhatsApp users, mainly young people; there are also studies on university students related to spelling and text messaging [52] and the general use of WhatsApp by higher education students [5].

Rodríguez-Morales and Rodríguez-Salazar [53] developed interesting research on the communicative practices of young people from the use of mobile technologies and their different applications and the handling of written language by incorporating symbols, emojis, and emoticons, which allow them to express emotions and reiterate points of view. Among the major results is the interest in internal messaging; they can use distinct possibilities to express an idea, for example, in text, video, audio, images, and emojis.

To a lesser extent, there are studies of emoticons or emojis on other educational levels; for example, the written norm in the conversations of postgraduate students was analyzed by Rodríguez-Morales and Rodríguez-Salazar [53]. Rubio [54] also covers this object of study but with students of basic primary education, where the children's interest in improving relationships and the climate generated in the classroom is reflected.

In a more general area, studies related to emoticons or emojis can also be identified from other themes and disciplines, for example, the analysis of feelings from their use [55], the multilingual author in social networks from the n-grams of characters of grammatical tags [16], the development of text summaries through the use of digital tools [18], or an investigation of the frequency of use in older adults [56].

Maíz-Arévalo [57] associates emojis with informal texts in virtual spaces such as sending emails, participating in chats using WhatsApp and Facebook, and using Twitter. However, it is also important to reflect on whether they are used in more formal spaces, their frequency of use, and the functions they perform. Rodriguez et al. [58] research the use of emoticons from the evaluation of seven dimensions: (i) aesthetic appeal, (ii) familiarity, (iii) visual complexity, (iv) clarity, (v) reflection of positive or negative emotion, (vi) emotion, and (vii) the meaning attributed to it.

Analyzing the main research on the problem, it is identified that the predominant age group for this type of study are university students. Moreover, there is a gap around the research with graduate students and the frequency of use of emojis in the WhatsApp groups they generate with 
their classmates, as well as the advantages and disadvantages they identify in this type of language. Some researchers stress that they are used only in informal spaces, and others point out they have also been incorporated into formal spaces.

Therefore, with this research, we want to fill this gap and focus on identifying the use of emojis in WhatsApp by graduate students, who have a long history in academia and can give us a better reflection of their employment in higher education. This will also allow us to observe the advantages and disadvantages of their use in the context studied. We consider that it is relevant to establish a study of these characteristics since it is located in formative contexts that have been little studied previously. They have almost always been carried out from a social perspective. Knowing the current situation in an educational environment can be very interesting to establish the evolution that these new languages may experience in the future and their impact on education.

\subsection{From Emoticons to Emojis}

It is, therefore, necessary to clarify some issues in the context of research. The main one is that today, one of the most used innovations is emojis [59-61], which are incorporated into the conversations that take place in chats through the use of different technological tools such as Facebook, Twitter, WhatsApp, and Hangouts. All of them respond to communicational acts such as gesticulation, the reaction to a situation [62], the manifestation of emotions, moods, and feelings [1], and they somehow replace the facial expressions that are a fundamental aspect of face-to-face conversation and include images that characterize the communication of people who share certain tastes, interests, and objectives [63].

Although the term emojis is mentioned in some texts as a synonym of emoticons, it is necessary to establish a distinction between both, as well as to identify the historical moment in which each of them starts to be used. In the Spanish-speaking context, in which we are located, and according to Real Academia Española (RAE), emoticons are defined as "the representation of a facial expression used in electronic messages to allude to the state of mind of the sender". It is a neologism that comes from emotion and icon, which refers to the emotion and the image. They are used particularly in TMCs, where they are considered a resource that allows conversations to be printed with gestures and handled as immediate feedback in the communicative process [64].

The invention of emoticons is attributed to Flahlman from Carnegie Mellon University, USA, who, three decades ago, represented a smiling face with punctuation marks using the computer keyboard, creating the symbol using three signs :-), and also used :-( to represent a sad or angry face. Originally, these combinations of symbols from a computer keyboard were used to identify jokes in a scientific computer forum; however, later, their use became widespread in TMCs to save time. They are defined by Cheng [14] as graphic representations of facial expressions that are embedded in electronic messages.

The origins of the term emoji are in Japan in early 1999, with the creation of i-mode, a mobile platform with Internet access designed by the company NTT DoCoMo. Shigetaka Kurita is considered the author of the design of 176 pictograms and gestures, with a size of $12 \times 12$ pixels, which were associated with Japanese culture and allowed the representation of emotions, objects, people, and animals [65-67]. Little by little, the emojis were extended to represent emotions in the systems of messaging [64].

Raimondo et al. [65] defined them as a paralinguistic element and also confirmed that their use in conversations has favored more expressive and informal communication, which is characterized by the graphic representation that each has, besides the diversity of meanings that can be attributed to it, from interpreting each user [64]. Its evolution and its acceptance have been such that it is considered a new language in today's society; the variety of designs is increased rapidly by incorporating new characters that contextualize situations that are lived, including news and events [59].

Currently, the number of emojis has exploded; they are added every year to Emojipedia, a term used by Jeremy Burgue in 2013 to refer to the encyclopedia that defines the icons on the web, which is in the following link: https://emojipedia.org/, where the different emojis are defined. Recently, there were about 2000 emoticons and emojis. 
Montenegro and Hermenegildo [64] say that the WhatsApp application is one of the most widely used technological tools today to establish communication with people asynchronously, make alls, share files, as well as images, videos, and audios. One of the most widely used resources in conversations are emojis, which facilitate the development of graphic messages that are incorporated into the talks through this application. They express gestures, emotions, feelings, and moods, including people and objectives [68-70].

The language used with the WhatsApp application has had such acceptance by users that you can already find words in Spanish as "vamos a wasapear", (exchange messages in WhatsApp) and "te mando un wasap" (message sent by WhatsApp). The RAE [71] has recognized this terminology as adaptations of the Spanish language.

The use of emojis in WhatsApp is based on Emojipedia and the approvals made by the Unicode Consortium. One of its most recent versions is 2017, which included 8518 new characters, and, of these, 56 corresponded to emojis (you can now talk using 136,690 characters, which include both emotions, faces, people, animals, nature, food, drink, travel, symbols, flag, and weather issues). This is a relatively recent phenomenon, which has not been studied in depth [72].

The incorporation of emojis in conversations has been justified by science, considering the following reasons: (i) increase in popularity of social networks, (ii) reactions by people when reading a message where they are included, (iii) they facilitate their inclusion in formal and negotiation spaces, (iv) they soften critical messages, (v) they make people seem more friendly and competent, (vi) they favor the development of virtual learning environments, and (vii) they can establish a correlation with happiness in real life [73].

Some authors [64,74] have pointed the interaction with emojis in the development of a conversation mediated by computers through the use of technological applications; in this case, WhatsApp favors the transmission of ideas and feelings, emphasizing content, views, and opinions. Sometimes, they replace the use of words, statements, or phrases with the use of a single image or a group of them; however, it also specifies that the meaning may vary from person to person, depending on the context, previous knowledge, references, characterization of the situation, as well as the degree of confidence that exists with the people with whom we communicate, whether friends, family, coworkers, fellow group members, authorities, partners, or collaborators.

In short, we are facing a new form of intercultural language that has a powerful presence in our society and is used by university students. It is worth asking, therefore, to what extent it has a presence in higher education and what use is made of this form of communication in this scientific and cultural space of such social relevance [75].

\section{Materials and Methods}

\subsection{Objectives}

We have determined that there is virtually no research on graduate students, the highest level in the academic world. It is very interesting, therefore, to identify the use of emojis in the WhatsApp application as a form of communication by this group. It should be borne in mind that graduate students are the ones who have been in the university environment for the longest time and, therefore, will offer us a more effective view of the rootedness that exists in the use of this symbolic language in higher education.

Therefore, we seek three objectives in this research: (i) to identify the frequency of use of emojis on WhatsApp in groups of graduate students; (ii) to analyze the advantages and disadvantages that these university users find in the incorporation of emojis into WhatsApp conversations, and (iii) identify the reasons college students use emojis.

To achieve these objectives, we place ourselves in the context of an exploratory study. The theoretical framework of the scientific architecture used is based on establishing, from the state of the question, the description of the current situation of the use of emojis as a new form of intercultural communication 
emerging in the digital paradigm. Additionally, it is especially interesting to place it in the field of higher education and to know the characteristics of this use within formative contexts and not only the social context, as it has mainly been done.

\subsection{Study Design and Sample}

This research was developed from a quantitative approach with a nonexperimental, descriptive, and cross-sectional design [76-78]. The technique used was the survey, which allows the use of a set of standardized procedures in research that enables the collection and analysis of data from a sample of representative data from a population [79]. We used the information collection instrument "Survey on the use of emojis in WhatsApp communication with group mates", created by us, which was applied to 103 subjects.

We developed a questionnaire consisting of 30 items, organized as follows. The first part is on sociodemographic data and the use of WhatsApp. It is composed, therefore, of two blocks: a first block, where identification data was requested: (1) age, (2) sex and (3) occupation (Items 1-3), and a second block around the frequency of use of WhatsApp (Items 4-6), with Questions (4) Do you use WhatsApp on your cell phone, (5) Frequency of use of WhatsApp, and (6) When you chat with your fellow group members, do you use emojis in your conversation?

The second part is composed of three blocks that are focused on knowing the different aspects of the use of emojis. The first block of this second part focuses on the reasons for the use of emojis in WhatsApp conversations, particularly in groups with fellow students (Items 1-21) and is distributed in different sections, for which a five-point Likert type scale is used with the following response options: always (4), almost always (3), sometimes (2), rarely (1), and never (0). A second block (Items 22-24) consists of open-ended questions about the more commonly used emojis, as well as advantages and disadvantages of use.

For the validation of content, the expert method was used [80] so the participation of 12 experts was requested, who have as their line of research the generation and application of knowledge and the use of technologies in a didactic way. They were invited to participate by email and, after their acceptance, they were sent a form on Google, where they evaluated each item from two perspectives: the first, if it belongs or not to the study construct, and the second, where they considered aspects of writing, relevance, coherence, and clarity. The analysis of their contributions allowed adjustments to the questionnaire and thus ensured the understanding of it.

Once the content validation was carried out, the questionnaire was applied to a pilot group made up of 50 subjects with similar characteristics to those it was subsequently applied to. For its part, the reliability of the scale has been evaluated with Cronbach's alpha $(\alpha)$. Except for the items related to the reference variables, in the items with a similar scale, an estimated coefficient of 0.92 was obtained on average. It exceeds the conventional levels, which denotes the high internal consistency of the questionnaire.

The sample was intentionally selected using a nonprobabilistic sample that consisted of 103 subjects who were studying for postgraduate degrees (master's and doctorate) in different Mexican universities, linked to the Educational Sciences, and who use WhatsApp as a technological application to get in touch with their fellow group members to establish one-to-one or group communication, highlighting as the main characteristic the use of emojis in their conversation. Most of the subjects taking part were in the age range of $23-35$ years $(74.7 \%), 36-40$ years $(19.4 \%)$, and over 40 years $(5.9 \%)$. Of the total sample, $25(24.3 \%)$ are men, and $78(75.7 \%)$ are women. In terms of occupation, the majority of those surveyed were teachers, which corresponds to $81.5 \%$ or 84 participants.

The application of the instrument was carried out online, using specific software for this purpose, and an invitation was made to respond to it by email. The protocol followed all the guidelines of the Ethics Committee of the universities to which the members of the research team belong. The Codes of Good Practice for Research on Human Beings were followed, which were collected by these committees and signed, and the study was registered by the research team that integrated 
the authors. All participants gave their informed consent, following the Declaration of Helsinki. The instrument used to collect the information, in the form of an online questionnaire, guaranteed confidentiality and anonymity. Participants had to accept the ethical conditions and give their consent before accessing the questionnaire and submitting their responses.

To process the information, the information matrix of the electronic form was exported to Microsoft Excel ${ }^{\circledR} 2016$ software, where the values of mean $(\bar{X})$, standard deviation $(s)$, and minimum and maximum were determined. Pearson's correlation coefficients were calculated using GraphPad Prism ${ }^{\circledR} 8.0$ software. Pearson's chi-square test was also applied with SPSS ${ }^{\circledR}$ Statistical Software version 25 , calculating the descriptive statistics according to each variable and category. The reason for applying these tests was to determine if there were significant differences in the sample in gender, age, or occupation. For example, if women use more emojis than men, or if the younger participants use them more than the older ones, or if, in some specific professions, they are more frequently used or used in a different way.

\section{Results}

Briefly, $100 \%$ of the respondents answered that they use the WhatsApp application on their cell phone. Of these, $102(99 \%)$ use it daily, and $1(1 \%)$ use it more than once a week. These data confirmed that the use of technological tools has increased considerably and in activities related to communicating clearly, such as WhatsApp.

Regarding the use of emojis in a conversation when chatting with fellow group members, 95 students $(92.2 \%)$ responded that they use them, and $8(7.8 \%)$ responded that they do not use them when developing a conversation concretely when establishing communication with their peers.

As for the reasons why they use emojis in the conversations they establish with their group mates, from the answers obtained, the mean $(\bar{X})$, standard deviation $(s)$, and minimum and maximum were calculated. This is shown in the following tables (Tables 1-5), divided into the categories: (1) social interactions, (2) expressing emotions and feelings, (3) understanding utensils, and (4) writing style.

Table 1. Social interactions. Source: own elaboration.

\begin{tabular}{lcccc}
\hline \multicolumn{1}{c}{ Item } & Mean $(\overline{\mathbf{X}})$ & $\begin{array}{c}\text { Standard } \\
\text { Deviation (s) }\end{array}$ & Minimum & Maximum \\
\hline 1. Demonstrate closeness & 2.78 & 1.28 & 0 & 4 \\
\hline 2. Generate empathy & 3.26 & 1.13 & 0 & 4 \\
\hline 3. Encourage socialization & 3.02 & 1.27 & 0 & 4 \\
\hline $\begin{array}{l}\text { 4. Strengthen trust in the group } \\
\text { 5. Strengthen social cohesion }\end{array}$ & 2.98 & 1.22 & 0 & 4 \\
\hline $\begin{array}{l}\text { 6. Promote peer interaction } \\
\text { 7. Generate a good collaborative work } \\
\text { environment }\end{array}$ & 2.73 & 1.24 & 0 & 4 \\
\hline $\begin{array}{l}\text { 8. Make the conversation more enjoyable } \\
\text { 9. Mediate the conversation with my }\end{array}$ & 3.00 & 1.16 & 0 & 4 \\
\hline colleagues & 2.82 & 1.11 & 0 & 4 \\
\hline
\end{tabular}


Table 2. Express emotions and feelings. Source: own elaboration.

\begin{tabular}{lcccc}
\hline \multicolumn{1}{c}{ Item } & Mean $(\overline{\mathbf{X}})$ & $\begin{array}{c}\text { Standard } \\
\text { Deviation (s) }\end{array}$ & Minimum & Maximum \\
\hline 10. Expressing my emotions & 3.14 & 1.28 & 0 & 4 \\
\hline 11. Manifesting my state of mind & 2.93 & 1.36 & 0 & 4 \\
\hline 12. Sharing my feelings & 2.83 & 1.44 & 0 & 4 \\
\hline
\end{tabular}

Table 3. Understanding of messages. Source: own elaboration.

\begin{tabular}{lcccc}
\hline \multicolumn{1}{c}{ Item } & Mean $(\overline{\mathbf{X}})$ & $\begin{array}{c}\text { Standard } \\
\text { Deviation (s) }\end{array}$ & Minimum & Maximum \\
\hline $\begin{array}{l}\text { 13. To better understand what has been } \\
\text { expressed }\end{array}$ & 2.87 & 1.32 & 0 & 4 \\
\hline $\begin{array}{l}\text { 14. Soften critical messages } \\
\text { 15. Emphasize content }\end{array}$ & 2.86 & 1.36 & 0 & 4 \\
\hline 16. Express doubts & 2.68 & 1.37 & 0 & 4 \\
\hline 17. Reiterate points of view and opinions & 2.55 & 1.31 & 0 & 4 \\
\hline
\end{tabular}

Table 4. Writing styles. Source: own elaboration.

\begin{tabular}{lcccc}
\hline \multicolumn{1}{c}{ Item } & Mean $(\overline{\mathbf{X}})$ & $\begin{array}{c}\text { Standard } \\
\text { Deviation (s) }\end{array}$ & Minimum & Maximum \\
\hline 18. Cut down on words & 2.37 & 1.40 & 0 & 4 \\
\hline 19. Send response more quickly & 2.68 & 1.42 & 0 & 4 \\
\hline 20. It is more practical & 2.68 & 1.41 & 0 & 4 \\
\hline 21. Attract attention & 2.65 & 1.39 & 0 & 4 \\
\hline
\end{tabular}

The category of social interactions comprises 9 items, the broadest one being where keywords such as closeness, empathy, socialization, trust, cohesion, interaction, friendly atmosphere, pleasant conversation, and mediation can be observed. The highest score is obtained by Item 8 (Make the conversation more pleasant), with an average of 3.31, and the lowest is reflected in Item 5 (Strengthen group cohesion), with 2.78 , presenting a difference between both of 0.53 . In general, the evaluation is positive for each of the items since all of them are above 2.5 (all this with the minimum in a range of 0 and the maximum in a range of 4 ).

This category presents the expression of emotions, moods, and feelings when using emojis, where the highest average corresponds to Item 10 (Expressing my emotions), and the lowest standard deviation is 1.28 , so the dispersion of data is lower, which reflects that the participants identify in the emojis a resource to express their emotions during the development of the conversations with their group mates. The item that gets the lowest score is 12 (Sharing my feelings). As in the previous category, a minimum of 0 and a maximum of 4 are presented as ranges. 
Table 5. Emojis used more frequently. Source: own elaboration.

\begin{tabular}{|c|c|c|c|}
\hline Emojis & $\begin{array}{l}\text { Number of } \\
\text { Emojis }\end{array}$ & Frequency & $\begin{array}{l}\text { Percentage of } \\
\text { Employment }\end{array}$ \\
\hline $\begin{array}{l}\text { Action of thinking, admiration, angel face, animals, } \\
\text { blessings, congratulations, detective lens, drinks, emotions } \\
\text { together, emotions, face crying of happiness, face of } \\
\text { annoyance, face of empathy, face of hands with hug, face } \\
\text { of question, face of surprise, face with clenched teeth, face } \\
\text { with doubt, faces in general, finger down, gifts, good } \\
\text { wishes, gratitude, hundred, intellectuals, love, of } \\
\text { confusion, of question, okay, party, peace, please, } \\
\text { recognition, reflection, relieved face, smiling face, } \\
\text { tenderness, thoughtful face, tired, turned face, uncertainty }\end{array}$ & 43 & 1 & $1.17 \%$ \\
\hline $\begin{array}{l}\text { Discomfort, eyes, flowers, girl raising her hand, glasses, } \\
\text { hand gestures, laughing }\end{array}$ & 7 & 2 & $2.35 \%$ \\
\hline $\begin{array}{c}\text { Applause, aware, doubt, goodbye, hands, in love, laughter, } \\
\text { moods, scared }\end{array}$ & 9 & 3 & $3.52 \%$ \\
\hline Ok & 1 & 4 & $4.70 \%$ \\
\hline Amazement, hands together, surprise, thoughtful & 4 & 5 & $5.88 \%$ \\
\hline Crying & 1 & 6 & $7.05 \%$ \\
\hline Greeting, sorry & 2 & 7 & $8.23 \%$ \\
\hline heart, hug, laugh, like & 4 & 8 & $9.41 \%$ \\
\hline Little faces, winkle & 2 & 10 & $11.76 \%$ \\
\hline Kiss & 1 & 11 & $12.94 \%$ \\
\hline Angry, sadness & 2 & 15 & $17.64 \%$ \\
\hline Finger pointed up & 1 & 18 & $21.17 \%$ \\
\hline Smile & 1 & 19 & $22.35 \%$ \\
\hline Happy face & 1 & 36 & $42.35 \%$ \\
\hline
\end{tabular}

The third category is composed of the use of emojis as a resource for understanding messages. It is made up of 5 items, where the highest average is for Item 13 (To better understand what you want to express), that is, besides the written text, its meaning is reinforced by the use of emojis; the lowest average is obtained by Item 16 (Express doubts), with a 2.55, getting a difference between the highest and lowest scores of only 0.32 . Once again, the minimum range is 0 , and the maximum is 4 .

Finally, in the fourth group, the items related to writing are identified (those made up of four), where the highest average is for Item 19 (Send answer more quickly) and Item 20 (It is more practical), with 2.68; the one with the lowest percentage is Item 18 (Save words). The questionnaire also offered three open questions to deepen the information previously obtained and to carry out a qualitative analysis of these responses. From Item 22 (Which emojis do you use most frequently?), a total of 290 responses were generated, with the participants mentioning one, two, or three emojis that they use most frequently. The way they stated them was by describing the emoji, writing down an emoticon (i.e., using the signs on the keyboard), or copying and pasting the emoji. In total, 79 emojis were identified as being the most frequently used in the conversations with their fellow students, generated in WhatsApp. How they were mentioned by the participants was respected; the results are shown in Table 5.

The first column lists the emojis mentioned by the participants as they wrote them in the survey, the second column shows the number of emojis, the third column shows the frequency with which they were used, and, finally, the fourth column shows the percentage that corresponds to that frequency, according to the total that was 79 . 
As can be seen in the results, which are presented in ascending order, that is, from the lowest percentage to the highest, the highest percentage is the happy face with 42 percent. It is followed, in second place, with $22.35 \%$, by the smiling face. The third place is occupied by the finger pointed up, with $21.17 \%$; the fourth place corresponds to present emotions of sadness and also of anger, with $17.64 \%$; in fifth place is the kiss with $12.94 \%$. These results confirm previous studies where different cultures across the East and the West were taken into account [81]. By contrast, another review of this topic indicates that the most popular emojis are "heart" and "tears of joy" [82]. In this sense, recent studies have confirmed that, depending on the culture considered, significant differences in the interpretation of the most commonly used emojis can be found [83]. Thus, the influence of different platforms and cultural heritage on the frequency of using a specific emoji is an aspect that needs further research.

Through an open question, the students were asked to write down the advantages they find when working with emojis in the conversations through WhatsApp that they have with their classmates with whom they study in graduate school, generating 132 responses. The reason why it exceeds the number of students is that several of them mentioned two reasons in this space.

After the analysis of each of the answers, categories were generated, making a total of 17 . In Table 6 , a list of these are presented in alphabetical order; in the second column, the frequency in which they were found is presented, and in the third column, the percentage they represent.

Table 6. Advantages of using emojis in student groups. Source: own elaboration.

\begin{tabular}{|c|c|c|}
\hline Category & Frequency & Percentage \\
\hline $\begin{array}{l}\text { Pleasant, relaxed, close, empathetic, trusting, } \\
\text { collaborative, flexible, fluid, enjoyable }\end{array}$ & 45 & $34.09 \%$ \\
\hline Express emotions, feelings, moods, and reactions & 26 & $19.69 \%$ \\
\hline Speeding up the conversation/Quick response & 11 & $8.33 \%$ \\
\hline Practicality & 8 & $6.06 \%$ \\
\hline Save time & 7 & $5.30 \%$ \\
\hline Improved message understanding & 7 & $5.30 \%$ \\
\hline Emphasize the meaning of the message & 6 & $4.54 \%$ \\
\hline Converse in a versatile, creative and visual way & 5 & $3.78 \%$ \\
\hline Soften messages & 4 & $3.03 \%$ \\
\hline Save words & 3 & $2.27 \%$ \\
\hline Show your personality & 3 & $2.27 \%$ \\
\hline Save characters & 2 & $1.51 \%$ \\
\hline Provide emotional tones & 1 & $0.75 \%$ \\
\hline Clarity of response & 1 & $0.75 \%$ \\
\hline Express points of view & 1 & $0.75 \%$ \\
\hline Avoid misunderstandings & 1 & $0.75 \%$ \\
\hline Reinforce the message & 1 & $0.75 \%$ \\
\hline
\end{tabular}

Within the highest percentages are, first, with $34.09 \%$, that the use of emojis in a group of colleagues on WhatsApp promotes an atmosphere of greater confidence, being relaxed, more closeness and collaboration, and being more flexible, which favors the flow of communication. In second place, $19.69 \%$ say that incorporating emojis to the conversations allow us to express, in some way, emotions, feelings, moods, and reactions. In principle, this is a help in this space of communication that is carried out asynchronously through technological tools most of the time, where, from the perspective of the participants, this use makes it possible not only to express ideas but also emotions. In third place, with $8.33 \%$, it is described that it increases agility in the conversation and the speed of response. 
As for the disadvantages of the use of emojis, specifically in WhatsApp conversation groups with fellow students, as the previous question was of open structure, 103 answers were generated. They correspond to the number of participants; from their analysis and review, 12 categories emerged, which are presented in alphabetical order in Table 7 (mentioning the frequency of occurrence and the corresponding percentage).

Table 7. Disadvantages of using emojis in student groups. Source: own elaboration.

\begin{tabular}{ccc}
\hline Category & Frequency & Percentage \\
\hline Misunderstand what was meant & 37 & $35.92 \%$ \\
\hline None & 16 & $15.50 \%$ \\
\hline Ambiguity, Confusion & 15 & $14.56 \%$ \\
\hline Informal / Not serious & 11 & $10.67 \%$ \\
\hline Vocabulary reduction & 11 & $10.67 \%$ \\
\hline Overuse & 6 & $5.82 \%$ \\
\hline Deviation of communication from the central theme & 3 & $2.90 \%$ \\
\hline Impaired interpersonal relationships & 1 & $0.97 \%$ \\
\hline The meaning of the information is lost & 1 & $0.97 \%$ \\
\hline Waste of time & 1 & $0.97 \%$ \\
\hline Image saturation & 1 & $0.97 \%$ \\
\hline
\end{tabular}

The results reflect that the most frequently mentioned category is that the use of emojis can produce misinterpretations in what was meant, with $35.92 \%$, because many times, in the participants' comments, there is a different definition or interpretation of emojis. They also mentioned that it depends on the mood or the moment they read the WhatsApp message, as well as, sometimes, the update number that their smartphone has and the type of operating system. It follows, $15.50 \%$ found no disadvantage of the use of emojis. Furthermore, thirdly, with $14.56 \%$, they found that the message can confuse or be ambiguous, as they mentioned that, sometimes, the reduction or elimination of words is increasingly frequent, and the interpretation is left only to the emojis used.

It should be added that, as we indicated, Pearson's chi-square test was also applied to calculate the descriptive statistics according to each variable and category, but no significant differences were found in the sample (gender, age, occupation). No dependency relationship was found; the significance value was greater than 0.05 in all cases. The use, therefore, of this communicative form by this group is very similar, even though it is a heterogeneous group.

\section{Discussion}

It is important to note that this type of language does not arise with the use of WhatsApp, but with the handling of signs to represent faces, mainly with moods of joy and sadness (for which the colon, semicolon, and parentheses were originally used). However, with the development of ICTs, these have been modernized and diversified in an accelerated way through different software and the use of the smartphone, which has generated interest in investigating this type of communication, which is carried out through technological tools. All of the above, however, are still in the process of development.

Investigations that delve into the study of this type of language have been carried out on different age groups [3,15], in older adults [56], with university students being one of the most analyzed groups $[4,5,14,18,20,50,52]$. However, in our case, we have additional information on the use of emojis in the field of graduate studies, i.e., students with a long history in the university world. In this sense, it contributes to a better understanding of the impact that the digital paradigm is having on higher education. Moreover, the complex processes in both formal and informal learning are being 
transformed today [36]. One of their multiple manifestations would be the case of emojis, which are already beginning to be studied in the educational field [43,83-87].

Nowadays, there is a growing demand for the need to be trained not only for life but for your entire life, to be updated, and to have more possibilities to occupy new job positions at the postgraduate level. This is the context in which, today, the mastery of ICTs is fundamental, of which these students are aware $[88,89]$. The diversity of groups within this group is also notable, since there are bachelor's degree graduates who immediately pursue a postgraduate degree, people who have a medium level of experience in the work environment, as well as people who have merged professional experience and a postgraduate program, so there is a diversity of ages [90-94]. This is also the case with profiles, for example, with postgraduate programs related to education. They are not necessarily graduates of careers such as pedagogy, educational sciences, preschool education, and elementary and high school; some people have a background in other disciplines and have decided to teach [95-97]. Its objective is to strengthen didactic and pedagogical issues, which is why there is diversity and richness in both age and training. In this heterogeneous context, however, we find that our study shows a great homogeneity in the use of emojis, which determines that their use is not very different between age and professional profiles.

About studies similar to ours, which allow us a comparison when making the documentary review of studies on the use of emojis at the postgraduate level, we only found the study of Gómez-Camacho and Gómez del Castillo [8], who analyzed the differential features of the conversations that take place on WhatsApp between Spanish students at the University of Seville. However, the objective they pursued differed greatly from ours since this study is oriented to analyze the conversations that are generated in that environment. They concluded that the digital norm in adult postgraduate students is characterized by a progressive approach to standard Spanish writing and is not related to an increase in misspellings in formal texts, as in previous studies. In our case, the focus of the work, although it coincides at the university educational level, was with graduate students from different Mexican universities, where their opinion has been noted concerning the interactions they establish concretely in WhatsApp groups with their peers. This has allowed us to quantitatively and qualitatively analyze their perceptions, points of view, and advantages and disadvantages in a general way of this new way of communication that has increased in people of different ages and the groups that are formed with friends, coworkers, and fellow students. There is, therefore, a great demand to investigate, from different perspectives, everything related to these new languages that have emerged in the digital paradigm [98-101].

As mentioned above, the culture considered is a key factor in the interpretation of the most commonly used emojis [63]. Thus, since this paper presents an exhaustive study for Mexican culture, it could be considered a new contribution to complete the vision of this subject in the different cultures of the world.

\section{Conclusions}

According to the results of this study, the frequency of use of emojis in WhatsApp amongst graduate students is increasing. Among the different uses (social interactions, expressing emotions, understanding messages, and writing styles), the highest percentages obtained are in the section of social interactions, highlighting that for the students, the most important thing about the use of emojis is to generate empathy and more enjoyable conversation and strengthen confidence. In this sense, in educational contexts and within learning models in mixed and online environments, emojis can be useful to strengthen social presence in the pedagogical designs themselves (creating an atmosphere of trust, a space for open communication, social cohesion, and group collaboration). It could be a matter of great interest for educational technologists in these innovative training frameworks.

The emojis that students use the most with their group mates are (i) the happy face, (ii) smiling, and (iii) the finger pointed up. It is important to point out that this is an interesting fact in these resources that accompany the processes of written communication in today's society through technological means 
since they determine that these languages present intercultural characteristics that are sometimes more direct than the use of spoken or written language.

According to the results, what stands out most about the emojis are their aspects related to the expression of emotions, feelings, and moods, saving time, a better understanding of the message, and the emphasis of some ideas. It is also stressed that the use of them reflects the personality of the person using them.

Emojis can confuse if the meaning is different for the sender and the receiver, which can cause misunderstanding as well as the deterioration of personal relationships. Furthermore, emojis consume valuable time and, occasionally, the attention is directed more towards the emojis than to the central message. Thus, excessive use of emojis reduces vocabulary and sometimes increases informal language. However, a significant percentage of students find no disadvantages in their employment.

The changes that have been generated in the communication processes (emoticons, emojis, stickers, customized avatars) and the strength that these have on the virtual learning environments in both informal and formal spaces has reached not only groups of family and friends but also colleagues and students. It allows us to recognize that communication is a fundamental resource for human beings, which are characterized by their social nature; this also shows the dynamic, dialectic, and ecosystemic elements that characterize the current communicative processes.

Regarding the main limitations of our study, we would like to indicate that the sample is smaller than we initially expected, but in the area of graduate studies, it is more difficult to achieve participation due to the academic and professional commitments within which most of these students work. Many are doing their master's thesis or doctoral dissertation and, at the same time, working in the educational field, in companies, and at the universities themselves. However, this work aims, in addition to the valuable data obtained, to determine the effectiveness of our instrument to collect the information sought. It serves us as a first study for other surveys that we will carry out later on in the international sphere. We are especially interested in offering joint results in the Latin American context, where there are no comparative studies in this regard.

We must also, as a limitation, base the results only on the answers given by the university graduates of Mexico. In future studies, it might be applicable to carry out an observation of actual usage. Nor have we carried out a triangulation of the data (for example, by using this questionnaire, observation, content analysis). Valuable data could also be obtained through research communities, such as "The Community of Inquiry (CoI)" (https://coi.athabascau.ca/). They would also give us information about the use of emojis in this area and how they can facilitate the speed of information communication and message exchange. This will be a work to be developed in future lines of research, in which the sample could also be extended to various countries in Latin America and at the international level. Another study that can be undertaken would be the comparison between the use of these new communicative languages among the population in general and in the university world in particular.

Author Contributions: Conceptualization, M.G.V.-B. and J.G.-G.; methodology, M.G.V.-B. and J.G.-G.; validation, M.G.V.-B., J.G.-G., and D.V.; formal analysis, M.G.V.-B., J.G.-G., and D.V.; investigation, M.G.V.-B., J.G.-G., and D.V.; data curation, M.G.V.-B. and J.G.-G.; writing-original draft preparation, M.G.V.-B., J.G.-G., and D.V.; writing-review and editing, J.G.-G.; supervision, M.G.V.-B., J.G.-G., and D.V.; project administration, M.G.V.-B., J.G.-G., and D.V. All authors have read and agreed to the published version of the manuscript.

Funding: This research received no external funding.

Acknowledgments: We greatly appreciate the effort made by the graduate students in this study. Although at this level, they are committed to important academic and professional work, they nevertheless participated with all the time necessary to guarantee objectivity and rigor in the entire process.

Conflicts of Interest: The authors declare no conflict of interest. 


\section{References}

1. López, A. Individuación y lenguaje no verbal en la CMC. Rev. Cienc. Soc. 2011, 1, 131-132. [CrossRef]

2. Machado, A.; Souza, M.J.; Catapan, A.H. Systematic review: Intersection between communication and knowledge. J. Inf. Syst. Eng. Manag. 2019, 4, em0086. [CrossRef]

3. Cuadrado, I.; Martín-Mora, G.; Fernández, I. La expresión de las emociones en la comunicación virtual: El Ciberhabla. ICONO 14 Rev. Comun. Tecnol. Emerg. 2015, 13, 180-207.

4. Gantiva, C.; Zarabanda, A.; Ricaurte, J.; Calderón, L.; Ortiz, K.; Castillo, K. Efecto de la empatía sobre el procesamiento cortical de emojis. Pensam. Psicol. 2018, 17, 7-17. [CrossRef]

5. Del Castillo, M.T.G. Utilización del WhatsApp para la Comunicación en Titulados Superiores. REICE Rev. Iberoam. Sobre Calid. Efic. Cambio Educ. 2017, 15, 51-65.

6. Tío, L.; Estrada, V.; González, W.; Rodríguez, R. Instrumento y herramienta informática para guiar, controlar y evaluar las interacciones de los estudiantes en foros virtuales. Educ. Médica Super. 2011, 25, 59-96.

7. Vlachopoulos, D.; Makri, A. Online communication and interaction in distance higher education: A framework study of good practice. Int. Rev. Educ. 2019, 65, 605-632. [CrossRef]

8. Gómez-Camacho, A.; Gómez del Castillo, M.T. La norma escrita en las conversaciones del WhatsApp de estudiantes universitarios. Rev. Mex. Investig. Educ. 2017, 22, 1077-1094.

9. Poleo, G. Análisis de las interacciones en un grupo de discusión asíncrono durante el desarrollo de un foro mediado por la web en un contexto universitario. Rev. Investig. 2011, 35, 267-290.

10. Rodríguez, F.J.; Ridao, S. La oralidad en educación secundaria. Didáctica. Leng. La Lit. 2012, 24, 341-358.

11. Seargeant, P. The Emoji Revolution: How Technology is Shaping the Future of Communication; Cambridge University Press: Cambridge, UK, 2019.

12. Martínez-Lirola, M. Aproximación a la interacción virtual: El caso de la red social Badoo. Palabra Clave 2012, 15, 107-127. [CrossRef]

13. Burholt, V.; Windle, G.; Gott, M.; Morgan, D.J. Technology-mediated communication in familial relationships: Moderated-mediation models of isolation and loneliness. Gerontologist 2020, 40. [CrossRef] [PubMed]

14. Cheng, L. ¿Digo lo que siento y siento lo que digo? Una aproximación transcultural al uso de los emoticonos y emojis en los mensajes en CMC. Fonseca 2017, 15, 199-217. [CrossRef]

15. Febres-Cordero, M.; Anzola, M. Las relaciones sociales derivadas del uso de las tecnologías en los procesos educativos virtuales. Educere 2019, 23, 27-37.

16. González-Gallardo, C.E.; Torres, J.M.; Rendón, A.M.; Sierra, G. Perfilado de autor multilingüe en redes sociales a partir de n-gramas de caracteres y de etiquetas gramaticales. Linguamática 2016, 8, 21-29.

17. Cervi, L. Comunidades virtuales de viajeros: Un caso de éxito. Univ. Rev. Cienc. Soc. Hum. Univ. Politécnica Sales. Del Ecuad. 2019, 30, 97-125. [CrossRef]

18. Lloret, E.; Palomar, M. Resúmenes de textos: Nuevos retos en la Web 2.0. Subj. Procesos Cogn. 2010, 14, 113-126.

19. López-Meneses, E.; Gómez-Galán, J. Prácticas Universitarias Constructivistas e Investigadoras con Software Social. Praxis 2010, 5, 23-45.

20. Giraldo, C.; Rios, D.; Cardona, F. La gramática al margen de la norma: La escritura en WhatsApp. Lenguaje 2018, 46, 311-333. [CrossRef]

21. Malcolm, J.; Hodkinson, P.; Colley, H. The interrelationships between informal and formal learning. J. Workplace Learn. 2003, 15, 313-318. [CrossRef]

22. Czerkawski, B.C. Blending formal and informal learning networks for online learning. Int. Rev. Res. Open Distrib. Learn. 2016, 17, 138-156. [CrossRef]

23. Ponce, O.A.; Pagan-Maldonado, N. Educational research in the 21st century: Challenges and opportunities for scientific effectiveness. IJERI Int. J. Educ. Res. Innov. 2017, 8, 24-37.

24. Mpungose, C.B. Are social media sites a platform for formal or informal learning? Students' experiences in institutions of higher education. Int. J. High Educ. 2020, 9, 300-311. [CrossRef]

25. Tang, S.Y.; Wong, A.K.; Li, D.D.; Cheng, M.M. The contribution of non-formal learning in higher education to student teachers' professional competence. J. Educ. Teach. 2017, 43, 550-565. [CrossRef]

26. López-Meneses, E.; Sirignano, F.M.; Reyes-Tejedor, M.; Cunzio, M.; Gómez Galán, J. European Innovations in Education: Research Models and Teaching Applications; AFOE: Seville, Spain, 2017.

27. Belyakova, E.G.; Zakharova, I.G. Interaction of university students with educational content in the conditions of information educational environment. Educ. Sci. J. 2019, 21, 77-105. [CrossRef] 
28. Berman, N. A critical examination of informal learning spaces. High. Educ. Res. Dev. 2020, 39, 127-140. [CrossRef]

29. Al-rahmi, W.M.; Zeki, A.M.; Alias, N.; Saged, A.A. Social media and its impact on academic performance among university students. Anthropologist 2017, 28, 52-68. [CrossRef]

30. Chugh, R.; Ruhi, U. Social media in higher education: A literature review of Facebook. Educ. Inf. Technol. 2018, 23, 605-616. [CrossRef]

31. Manca, S. Snapping, pinning, liking or texting: Investigating social media in higher education beyond Facebook. Internet Higher Educ. 2020, 44, 100707. [CrossRef]

32. Zachos, G.; Paraskevopoulou, E.A.; Anagnostopoulos, I. Social media use in higher education: A review. Educ. Sci. 2018, 8, 194. [CrossRef]

33. Aleksandrova, Y.G.; Parusheva, S.S. Social media usage patterns in higher education institutions-An empirical study. Int. J. Emerg. Technol. Learn. 2019, 14, 108-121. [CrossRef]

34. Kumar, V.; Nanda, P. Social media in higher education: A framework for continuous engagement. Int. J. Inf. Commun. Technol. Educ. 2019, 15, 97-108. [CrossRef]

35. Luo, T.; Freeman, C.; Stefaniak, J. Like, comment, and share. Professional development through social media in higher education: A systematic review. Educ. Technol. Res. Dev. 2020,68, 1659-1683. [CrossRef]

36. Greenhow, C.; Lewin, C. Social media and education: Reconceptualizing the boundaries of formal and informal learning. Learn. Media Technol. 2016, 41, 6-30. [CrossRef]

37. Friesen, N.; Lowe, S. The questionable promise of social media for education: Connective learning and the commercial imperative. J. Comput. Assist. Learn. 2012, 28, 183-194. [CrossRef]

38. Tess, P.A. The role of social media in higher education classes (real and virtual). A literature review. Comput. Hum. Behav. 2013, 29, A60-A68. [CrossRef]

39. Manca, A.; Whitworth, A. Social media and workplace practices in higher education institutions: A review. J. Soc. Media Soc. 2018, 7, 151-183.

40. Greenhow, C.; Galvin, S.M.; Staudt Willet, K.B. What Should Be the Role of Social Media in Education? Policy Insights Behav. Brain Sci. 2019, 6, 178-185. [CrossRef]

41. Gómez-Galán, J. Transformación de la educación y la universidad en el postmodernismo digital: Nuevos conceptos formativos y científicos. In La Era de las TIC en la Nueva Docencia; Durán, F., Ed.; McGraw-Hill: Madrid, Spain, 2014; pp. 171-182.

42. Gómez-Galán, J. Innovation and ICTs in Education: The Diversity of the 21st-Century Classroom; River Publishers: Aalborg, Denmark, 2020.

43. Gilles-Doiron, J.A. Emojis: Visual communication in higher education. Upil Int. J. Teach. Educ. Learn. 2018, 2, 1-11. [CrossRef]

44. Sampietro, A. Exploring the puctuating effect of emoji in Spanish WhatsApp Chats. Leng. Mod. 2016, 47, 91-113.

45. Spilioti, T. From transliteration to trans-scripting: Creativity and multilingual writing on the internet. Discourse Context Media 2019, 29, 100294. [CrossRef]

46. McCulloch, G. Because Internet: Understanding the New Rules of Language; Riverhead Books: New York, NY, USA, 2020.

47. Yus, F. Not all emoticons are created equial. Ling. (Dis)curso 2014, 14, 511-529. [CrossRef]

48. Al-Sharqi, L.; Abbasi, I.S. The influence of technology on English language and literature. Engl. Lang. Teach. 2020, 13, 1-7.

49. Prieto-Terrones, P.; Sanz-Martín, B.E. La ciberlengua empleada en WhatsApp. Un estudio de actitudes y creencias lingüísticas. Investig. Cienc. 2019, 27, 74-84.

50. Cantamutto, L.; Vela, C. Emojis frecuentes en las interacciones por WhatsApp: Estudio comparativo entre dos variedades del español (Argentina y España). Circuito Lingüíst. Apl. A Comun. 2018, 77, 171-186.

51. Giraldo, C. La dicotomía difusa contra la dicotomía tradicional oral/escrito. La escritura por WhatsApp. Prax. Saber 2018, 9, 1-12. [CrossRef]

52. Gómez-Camacho, A.; Gómez del Castillo, M.T. Escritura ortográfica y mensajes de texto en estudiantes universitarios. Perf. Educ. 2015, 37, 91-104. [CrossRef]

53. Rodríguez-Morales, Z.; Rodríguez-Salazar, T. Los jóvenes, la comunicación afectiva y las tecnologías: Entre la ritualización de la expresión y la regulación emocional. Intersticios Soc. 2016, 11, 1-34.

54. Rubio, A. Conociendo nuestra población a través de las emociones. Fórum Recer. 2017, 27, 69-80. [CrossRef]

55. Abdellaoui, H.; Zrigui, M. Using tweets and emojis to build TEAD: An Arabic dataset for sentiment analysis. Comput. Sist. 2018, 22, 777-786. [CrossRef] 
56. Briede-Westermeyer, J.C.; Pérez-Villalobos, C.E. Aproximación inductiva a la vida cotidiana de adultos mayores de Chile. Interciencia 2019, 44, 332-339.

57. Maíz-Arévalo, C. Emoticons in transational and interactional exchanges: Social networking chitchat versus working negotiation. Odisea 2016, 17, 19-35.

58. Rodríguez, D.; Prada, M.; Gaspar, R.; Garrido, M.; Lopes, N. Lisbon Emoji and Emoticon Database (LEED): Norms for emoji and emoticons in seven evaluative dimensions. Behav. Res. 2018, 50, 392-405. [CrossRef] [PubMed]

59. Menéndez, L. Más que simples "emojis". Escr. Pública 2020, 34, 18-19.

60. Sampietro, A. Emoji and rapport management in Spanish WhatsApp chats. J. Pragmat. 2019, 43, 109-120. [CrossRef]

61. Moussa, S. An emoji-based metric for monitoring consumers' emotions toward brands on social media. Mark. Intell. Plan. 2019, 37, 211-225. [CrossRef]

62. Lugo, M. La construcción de la imagen visual y la rostricidad en Facebook. Razón Palabra 2013, 83, 1-9.

63. Martínez-Ortega, C.; Pecourt, J. La comunicación móvil ritualizada: Una aproximación desde la microsociología. Sociología 2019, 34, 107-136. [CrossRef]

64. Montenegro, D.J.; Hermenegildo, E.A. Características del uso de emojis en la comunicación por el chat de WhatsApp. Hamutay 2018, 5, 36-52. [CrossRef]

65. Sampietro, A. Emoticonos y multimodalidad. El uso del pulgar hacia arriba en WhatsApp. Aposta. Rev. Cienc. Soc. 2016, 69, 271-295.

66. Mathews, S.; Lee, S.E. Fashion brands' use of emojis on Twitter: An exploratory study. Fash. Style Pop. Cult. 2019, 6, 319-332. [CrossRef]

67. Moussa, S. Complaining with emojis: Some conceptual and analytical aspects. Appl. Mark. Anal. 2020, 5, 256-265.

68. Raimondo, N.; Cardoso, A.L.; Rostagno, J.; Matías, A. Recursos paratextuales y paralingüísticos en las Fanpages de los periódicos argentinos Clarín y la Nación. Atributos del discurso de la prensa en las redes. Perspect. Comun. 2019, 12, 245-280. [CrossRef]

69. De Angeli, D.; Kelly, R.M.; O’Neill, E. Beyond Happy-or-Not: Using emoji to capture visitors' emotional experience. Curator Mus. J. 2020, 63, 167-191. [CrossRef]

70. Du Plessis, T. Interpretation of Emojis in Organisational Computer-Mediated Communication (CMC) Contexts. Master's Thesis, Stellenbosch University, Stellenbosch, South Africa, 2020.

71. Real Academia Española (RAE). Available online: https://www.rae.es/ (accessed on 13 October 2020).

72. Pérez, M. La comunicación no verbal en la interacción digital y su aplicación a la enseñanza de ELE. E-Eleando 2019, 13, 1-118.

73. Europa Press. ¿Por qué usamos emoticonos? 2015. Available online: https://www.laopiniondemurcia.es (accessed on 31 July 2020).

74. Cetinkaya, L. The impact of WhatsApp use on success in education process. Int. Rev. Res. Open Distrib. Learn. 2017, 18, 59-74. [CrossRef]

75. Gómez-Galán, J. Internet y la palabra: Un nuevo paradigma comunicativo en la cultura y la educación del siglo XXI. El Patrimonio Cultural: Tradiciones, Educación y Turismo; En, E., Martos, Y.A., Martos, A., Eds.; Instituto Cultural El Brocense: Cáceres, Spain, 2009; pp. 171-183.

76. De Zubiría, J.; Ramírez, A. Cómo Investigar en Educación; Editorial Magisterio: Bogota, Colombia, 2014.

77. Rojas, M. Tipos de investigación científica. Una simplificación de la complicada incoherente nomenclatura y clasificación. Redvet. Rev. Electrónica Vet. 2015, 16, 1-14.

78. Berger, A.A. Media and Communication Research Methods: An Introduction to Qualitative and Quantitative Approaches; Sage Publications: Thousand Oaks, CA, USA, 2018.

79. Casas, J.; Repullo, J.R.; Donado, J. La encuesta como técnica de investigación. Elaboración de cuestionarios y tratamiento estadístico de los datos. Aten Primaria 2003, 31, 143-162.

80. Barraza, A. La Consulta a Expertos Como Estrategia Para la Recolección de Evidencias de Validez Basadas en El Contenido; Universidad Pedagógica de Durango: Durango, Mexico, 2007.

81. Guntuku, S.G.; Li, M.; Tay, L.; Ungar, L.H. Studying Cultural Differences in Emoji Usage across the East and the West. In Proceedings of the Thirteenth International AAAI Conference on Web and Social Media (ICWSM 2019), Munich, Germany, 11-14 June 2019; pp. 226-235.

82. Bai, Q.; Dan, Q.; Mu, Z.; Yang, M. A systematic review of emoji: Current research and future perspectives. Front. Psychol. 2019, 10, 2221. [CrossRef] 
83. Fane, J.; MacDougall, C.; Jovanovic, J.; Redmond, G.; Gibbs, L. Exploring the use of emoji as a visual research method for eliciting young children's voices in childhood research. Early Child Dev. Care 2018, 188, 359-374. [CrossRef]

84. Algharabali, N.A.; Taqi, H.A. Taming the Sting: The Use of Evaluative Emojis by College Students in Kuwait. Int. J. Linguist. Commun. 2018, 6, 46-60. [CrossRef]

85. Al Qunayeer, H.S.; RahmtAllah, E.A. Using Emoji to Improve Female Students' Coherence in Writing at Qassim University. Adv. Lang. Lit. Stud. 2019, 10, 57-62. [CrossRef]

86. Bernal, M.L.; Gonella, F. Emojis Universitarios: La Representación de las Emociones del Estudiante Universitario. Master Thesis, Universidad Nacional de Rosario, Rosario, Argentina, 2020.

87. Vareberg, K.R.; Westerman, D. To:-) or to $\odot$, that is the question: A study of students' initial impressions of instructors' paralinguistic cues. Educ. Inf. Technol. 2020, 25, 4501-4516. [CrossRef]

88. Chui, S. A comparative study of the interpretations of emojis in between U.S. and Chinese users. Int. J. Lit. Arts. 2020, 8, 108-118. [CrossRef]

89. Concepción, J.D.C.; Veytia, M.G.; Gómez-Galán, J.; López, E.L. Integrating the digital paradigm in higher education: ICT training and skills of university students in a European context. Int. J. Educ. Excell. 2019, 5, 47-64. [CrossRef]

90. Gómez-Galán, J.; Vázquez-Cano, E.; López-Meneses, E.; Fernández-Márquez, E. Estudio de las tecnologías de la información y la comunicación desde la visión del estudiantado universitario. In Experiencias en Innovación Docente y Aportes de Investigación sobre la Praxis Universitaria; Gómez-Galán, J., Cáceres, P., Delgado, E., López-Meneses, E., Eds.; Octaedro: Barcelona, Spain, 2019; pp. 7-20.

91. Gittings, G.; Bergman, M.; Shuck, B.; Rose, K. The impact of student attributes and program characteristics on doctoral degree completion. New Horiz. Adult Educ. Hum. Resour. Dev. 2018, 30, 3-22. [CrossRef]

92. Veytia, M.G.; Gómez-Galán, J.; Morales, M.B. Competencias investigativas y mediación tecnológica en doctorandos de Iberoamérica. IJERI Int. J. Educ. Res. Innov. 2019, 12, 1-19.

93. Bekova, S. Does employment during doctoral training reduce the PhD completion rate? Stud. High. Educ. 2019, 45, 1-13. [CrossRef]

94. Yazar, T. Opinions and suggestions of graduate students about postgraduate education. Int. Online J. Educ. Sci. 2020, 12, 149-171.

95. Geeregat, O.; Cifuentes, G.; Villarroel, M.C. Factores que inciden en las condiciones de empleabilidad de los egresados de pedagogía. Actual. Investig. En Educ. 2016, 16, 383-402. [CrossRef]

96. Murillo, F.; Montaño, P.Y. Condiciones laborales de egresados de Instituciones de Educación Superior en México. Rev. Electrónica Investig. Educ. 2018, 20, 56-68. [CrossRef]

97. Perales, F.D.J. Estudio de egresados en un programa de posgrado en educación. Alteridad. Rev. Educ. 2020, 15, 256-269. [CrossRef]

98. Rodríguez de las Heras, A. Metáforas de la Sociedad Digital: El Futuro de la Tecnología en La Educación; Editorial SM: Madrid, Spain, 2015.

99. Sirignano, F.M.; Gómez-Galán, J.; López-Meneses, E. Investigación y Prácticas Universitarias; Universidad de Alicante: Alicante, Spain, 2018.

100. Kóczy, J.B.; Komlósi, L.I. Revisiting literacy: Changing learning paradigms in digital culture. Argumentum 2019, 15, 117-132.

101. Gómez-Galán, J. Media education in the ICT era: Theoretical structure for innovative teaching styles. Information 2020, 11, 276. [CrossRef]

Publisher's Note: MDPI stays neutral with regard to jurisdictional claims in published maps and institutional affiliations.

(C) 2020 by the authors. Licensee MDPI, Basel, Switzerland. This article is an open access article distributed under the terms and conditions of the Creative Commons Attribution (CC BY) license (http://creativecommons.org/licenses/by/4.0/). 